\title{
WHEN FORMAL ORGANISATIONS MEET INFORMAL RELATIONS IN SOVIET LITHUANIA: ACTION NETS, NETWORKS AND BOUNDARY OBJECTS IN THE CONSTRUCTION OF THE LITHUANIAN SEA MUSEUM
}

\author{
Eglè Rindzevičiūtè
}

\begin{abstract}
This study considers organisation in countries under the Soviet regime. The focus is on the creation of the Sea Museum in Klaipeda from the 1960 s to the 1980s, a massive undertaking that required huge capital investments, use of rare foreign materials, cooperation between many different sectors (Soviet military, heritage preservation, seaport management, seagoing fishing vessels and zoos in Eastern bloc countries), and many innovations in designing the local sea aquarium system. The whole project was formally illegal: there was an all-union wide restriction on building so-called 'spectator venues'. This article analyses the roles of formal and informal relations in the construction of the Sea Museum as a project concerning the public good. It suggests that the presence of informality did not undermine formal organising in the overtly centralised Soviet regime. Belonging to formal organisations was an important resource for actors who constructed action nets that went beyond the boundaries of these organisations. Although it is widely known that the successful functioning of formal organisations often depended on informal relations, this point raises complex questions about the identity and uniqueness of the Soviet system.
\end{abstract}

Introduction Prevailing theories assume that the coordination and control of activity are the critical dimensions on which formal organizations have succeeded in the modern world ${ }^{I}$. This assumption is based on the view that organizations function according to their formal blueprints: coordination is routine, rules and procedures are followed, and actual activities conform to the prescriptions of formal structure. However, much of the empirical research questions this assumption. ${ }^{2}$

${ }^{1}$ I would like to thank the participants in the seminar Being in the Soviet Network, Vilnius, 11-12 November 2010, for enlightening discussion of an early version of this paper. I am also especially grateful to Barbara Czarniawska and Kajsa Lindberg for their useful comments. The views expressed and any errors are the author's only.

${ }^{2}$ J.W. Meyer and B. Rowan, 'Institutionalized Organizations: Formal Structure as Myth and Ceremony', American Journal of Sociology, 83 (1977), p. 342. 
J.W. Meyer and B. Rowan criticised this normative belief in formal organisation because empirical observations show that 'structural elements are only loosely linked to each other and to activities, rules are often violated, decisions are often unimplemented, or if implemented have uncertain consequences'. ${ }^{3}$ This argument is often taken as a sign of downplaying the importance of formal organisation, though neither Meyer and Rowan nor I, following their example, interpret it in this way. The idea of formal and rational organisation, according to Meyer and Rowan, performs an important function in organisational life as a ceremonial myth that plays a vital role in shaping practices. ${ }^{4}$ What this view of formal organisation as a ceremonial myth actually suggests is that organising takes place through both formal and informal means. Informality does not necessarily undermine the formal organisation; quite the opposite, informality may be a necessary condition for the survival of formal organisation.

It has been a tradition in Soviet studies to analyse Soviet governance mainly through components of formal organisation, such as censorship, surveillance and centrally commanded and administered planning. These modes of governance were criticised as examples of Weberian formal rationality, which either failed or brought about disastrous consequences. ${ }^{5}$ However, little has been written about the productive role of informality, which lurked hidden behind ceremonially broadcast rational organising. In the case of the Soviet Union, what was the 'centrally planned economy' if not a legitimising myth? Soviet actors ceremonially recognised 'central planning', but then conducted their activities as they saw fit, and not always according to the prescriptions of central plans. It is time to reconsider this persistent informality as an important element of organising and not merely a sign of the failure of formal and rational structures.

This study, therefore, seeks to contribute to a more balanced understanding of the relationship between formal and informal organis-

${ }^{3}$ Ibid., p. 343.

${ }^{4}$ Meyer and Rowan describe myths of formal organisational structure as 'rationalized and impersonal prescriptions that identify various social purposes as technical ones and specify in a rule-like way the appropriate means to pursue these technical purposes rationally (...). Second, they are highly institutionalized and thus in some measure beyond the discretion of any individual participant or organization', ibid., pp. 343-344.

${ }^{5}$ J.C. Scott, Seeing Like a State: How Certain Schemes to Improve the Human Condition Have Failed (Yale, 1999); Z. Bauman, Modernity and the Holocaust (Cambridge, 1989). 
ing under the Soviet regime. The case is the creation of the Sea Museum, which was developed under the auspices of the Local History Museum and the Culture Department of the Klaipeda City Council of the Lithuanian Soviet Socialist Republic (LSSR). What is especially interesting about this case of organising is that the whole project was formally illegal. Since the 1960s construction of 'spectator venues' was tightly controlled in all Soviet republics, as scarce resources were first and foremost channelled to constructing industrial buildings and housing. The construction of the Sea Museum was kept secret from Moscow for six years. ${ }^{6}$ The most significant fact is that the whole project was realised almost entirely outside the formal planning process: the Sea Museum was created through informal organising that took place among formal organisations.

Networks, action nets and non-human actors A brief review of previous studies of formal and informal organising in the Soviet Union is required here. Several schools of thought could be distinguished but all tend to share an assumption that informal associations in the Soviet Union were either created in explicit opposition to the official regime or emerged despite formal organisations. Scholars adhering to this view call themselves 'revisionist' because they seek to revise another popular view, the so-called 'totalitarian approach', according to which the Soviet government thoroughly pervaded and controlled the entire society. Revisionists, in contrast, traced manifestations of societal deviance from the official norms of Soviet state institutions and even labelled various informal associations 'a Soviet civic society'. Since the 1970 s a third approach has been developed, which suggested the idea of 'a second economy' or 'informal economy' as a device for understanding the workings of the Soviet system that went beyond official planning and administration. ${ }^{7}$ Both revisionists and students of the 'second economy', however, continued to operate with a clear-cut opposition between state (formal) and society (informal) organisations.

A different approach was formulated within the revisionist paradigm by the sociologist Alena Ledeneva in the 1990s. Ledeneva investigated practices of 'an economy of favours', a system of informal

${ }^{6}$ A. Každailis, Smagios sunkios dienos (Vilnius, 2009), p. 50. Although support of some local leaders was ensured, for instance, the head of the State Planning Institute of the Lithuanian SSR was involved in the process.

${ }^{7}$ G. Grossman, 'The Second Economy of the USSR', Problems of Communism, 26, No. 5 (1977), pp. 25-40. 
relations that was called blat in Soviet Russia. ${ }^{8}$ Importantly, Ledeneva stressed that blat practices did not need to become stabilised into a network: it could involve very weak ties or contacts that were never activated before or after one time contact. Blat relations, according to Ledeneva, were not limited to barter exchange, but included provision of access to services, goods and resources. Further, such informal relations that lead to better access were not necessarily reciprocal. ${ }^{9}$ In the language of organisation theory, blat could be regarded as an excellent example of knotting an action net. According to organisation scholars Kajsa Lindberg and Barbara Czarniawska,

In an action net perspective ... actions come first and actors second with networks possibly but not necessarily third. As a first step, actors acquire an 'actorial' identity from actions, not the other way around. A contractor becomes a contractor not simply by becoming known as a contractor, but by providing what is required to construct a building. Past actions build up an actor's reputation, and it is the stability of their identities that gives 'character' to 'actants'. ${ }^{10}$

Called into being when something needs to be done, action nets transcend formal roles and the boundaries of particular organisations. Action nets precede networks, or already stabilised groupings of defined actors. An action net may or may not stabilise into a network. The network, in turn, would further stabilise the identities of actors or their roles in that particular system of practices.

Coined in order to shift the focus of study from actors to actions, the notion of the action net has the potential to highlight somewhat neglected aspects of informality in the Soviet Union. Soviet informality, most often captured in the special word blat, has been generally regarded as a unique and thoroughly negative phenomenon. ${ }^{11}$ For example, having defined informality as a particular mode of organising that was inherent to authoritarian regimes, Ledeneva described informal organising as an obstacle to liberal democracy. In contrast to

${ }^{8}$ The Russian word blat is not synonymous with bribery. Although officially blat was regarded as a vice, former Soviet actors retrospectively take pride in blat practices. For example, the Soviet Lithuanian minister of culture in his memoirs defended the Soviet economy of favours: 'a bribe? Phew! Only innocent signs of respect, attention to the Centre'; L. Šepetys, Neprarastoji karta: siluetai ir spalvos (Vilnius, 2005), p. 78.

${ }^{9}$ A. Ledeneva, Russia's Economy of Favors: Blat, Networking and Informal Exchange (Cambridge, 1998), pp. 35-36.

${ }^{10} \mathrm{~K}$. Lindberg and B. Czarniawska, 'Knotting the Action Net, or Organizing between Organizations', Scandinavian Journal of Management, 2006, p. 294.

${ }^{11}$ See, e.g., V. Ivanauskas, 'Sovietinių biurokratų darbo etika, neformalios rutinos ir planavimo sistemos trūkumai (Lietuvos atvejis)', Filosofija. Sociologija, 2006, No. 4, pp. 1-12. 
Ledeneva I suggest understanding informality as a universal element of organising and not just a vice that developed under authoritarianism. ${ }^{12}$ In authoritarian states and liberal democracies, formal organisation was performed as a ceremonial myth, which obscured but did not negate the importance of informality. The case analysed below will show that informal relations derived their power from being anchored in formal organisations. It was a loose coupling between formal organisations and the construction of informal action nets that made it possible to get done things which were not included in central plans. ${ }^{13}$

In colloquial use, blat was largely attributed to individual human actors; Ledeneva, for example, pointed out that it was something that common people did in their everyday lives. ${ }^{14}$ Furthermore, the social network approach also focused on human individuals and relations between them. From this point of view, it was humans who constituted the non-Soviet or anti-Soviet society and who were the harbingers of transformation of the authoritarian regime. Humans and humans only submerged post-Soviet countries in a swamp of corruption. ${ }^{15}$

${ }^{12}$ Ledeneva, for example, writes that 'Informal practices are often justified as a rational response to perceived defects in formal rules and their enforcement, but they are also indicative of defects in informal norms, both producing and resulting from distrust of public institutions and disregard for formal rules', A. Ledeneva, How Russia Really Works: The Informal Practices That Shaped Post-Soviet Politics and Business (Ithaca-London, 2006), p. 27. Ledeneva correctly observes that formal and informal relations are closely interrelated (Ledeneva, Russia's Economy of Favours, p. 85-86). However, she holds that informal practices merely helped to keep the 'Soviet command economy afloat' and later became an obstacle to democratisation.

${ }^{13}$ Existing accounts of everyday life under Soviet regime testify that there was something particularly vicious and enslaving in the pervasive Soviet informality, unpredictable application of formal rules and lack of trust in formal organisation. Ledeneva's work proves this point. It is therefore not sufficient to focus on modes of organising or 'how'; one should also explore the objects of organising or 'what'. It is only by focusing on 'what was organised' that we can understand the particularities or universalities of the Soviet regime. Informal organising could be used to create the public good, for instance, a museum. However, informal organising could also be used to create closed networks of exclusive privilege, covering up and corruption. The creation of public goods and intensifying of nepotism could go hand in hand.

${ }^{14}$ Ledeneva, Russia's Economy of Favours, p. 46. In her studies Ledeneva outlines a rich taxonomy of informal relations in Soviet and post-Soviet Russia and describes these relations with local categories, such as blat, krugovaia poruka.

${ }^{15} \AA$ A. B. Grødeland, "'Red Mobs", "Yuppies", "Lamb Heads" and Others: Contacts, Informal Networks and Politics in the Czech Republic, Slovenia, Bulgaria and Romania', Europe-Asia Studies, 59, No. 2 (2007), pp. 220-221. Although Grødeland does admit that informal networks are not vicious by themselves, but can be used for legitimate or illegitimate purposes, she also identifies formal organisation with democratic governance. 
One could argue, however, that at least one important type of 'actant' is missing from the social network approach, namely, nonhuman actors. ${ }^{16}$ Materiality is crucially important to any organisation, network or action net. According to the Online English Dictionary, a network is 'work (esp. manufactured work) in which threads, wires, etc., are crossed or interlaced in the fashion of a net'. This linguistic definition alone suggests that networks do not hover in human minds, but are made from material things, such as (telephone) wires or threads (of documents). This constructed and material nature of networks was highlighted in actor-network-theory (ANT). As B. Latour puts it, social relations are always embodied and stabilised through materiality. ${ }^{17}$ It could be that the omission of the material aspect in most Soviet studies is a side effect of the rejection of Marxist thought, which emphasised the role of materiality. Yet the case of the creation of a new museum, analysed below, shows how non-human actors stimulated both formal cooperation between organisations and uses of informal ties.

In stimulating cooperation in this way, material things perform as boundary objects: they simultaneously participate in multiple material, cultural, techno scientific, social and political worlds. According to S.L. Star and J.R. Griesemer, who studied the construction of Berkeley's Museum of Vertebrae Zoology, boundary objects

... have different meanings in different social worlds but their structure is common enough to more than one world to make them recognizable, a means of translation. The creation and management of boundary objects is a key process in developing and maintaining coherence across intersecting social worlds. ${ }^{18}$

The process of building the Sea Museum and assembling its collections reveals the creation of boundary objects, which at the same time participated in natural, cultural and political worlds. Once the construction of the Sea Museum is understood as the management of

${ }^{16}$ The term 'actant' was coined by the Lithuanian-French semiotician A.J. Greimas to describe an actor, human or non-human, that performs a role in a certain narrative programme. 'Actant' was introduced into social science by B. Latour and M. Callon in the 1980s and became part of the new analytical apparatus developed within actor-network-theory (ANT).

${ }^{17}$ B. Latour, Reassembling the Social: An Introduction to Actor-Network-Theory (Oxford, 2005).

${ }^{18}$ S. Leigh Star and J.R. Griesemer, "Institutional Ecology, "Translations" and Boundary Objects: Amateurs and Professionals in Berkeley's Museum of Vertebrate Zoology, 1907-39', Social Studies of Science, 19 (1989), p. 393. 
boundary objects, it becomes pointless to try and pinpoint this museum either as an achievement of the official Soviet regime or as resistance to the official system, particularly central planning. The completion of the Sea Museum was a resolution but not consensus, to put it in Star and Griesemer's words. The Sea Museum emerged thanks to the skilful acts of translation between different worlds, which belonged to Russian and Lithuanian communist officials, but also sailors and heritage specialists and city administrators, seals and penguins.

\section{'Legally Illegal': The Klaipèda Sea Museum (Aquarium) Initi-} ated in 1969, formally established in 1976 and opened to visitors in 1979, the Sea Museum was the most visited museum in Lithuania in 2009. Having annually attracted over 400,000 visitors, the Sea Museum, unusual for a public cultural sector organisation, generated reasonable profit. ${ }^{19}$ In 2011, the Sea Museum boasted a large collection of 957 live exhibits, among which there were such exotic creatures as sea lions and dolphins..$^{20}$ Located not in the capital, but in the seaport city that is third in size in the country, the Sea Museum is a fascinating case that challenges the historian to reconsider so many aspects of Lithuania's history in the second half of the twentieth century, such as local patriotism beyond ethnicity, instruments of control and spaces of autonomy in Soviet cultural policy, transfer of knowledge and last but not least modes of organising complex projects. Perhaps the most striking part of this story is that although the construction of the Sea Museum was illegal, its creators were awarded the State Prize of the Lithuanian SSR in 1982. ${ }^{21}$

The case of the Klaipeda Sea Museum testifies to the highly productive role that informality could assume under the Soviet regime.

$19<$ http://www.stat.gov.lt/lt/news/view/?id=8752> [address visited on 1 Aug. 2011]. For example, the Sea Museum received less than other state museums in state subsidy per visitor and earned more per visitor in 1998 and 1999. 'Valstybès išlaidos kultūrai ir muziejams', Muziejininkystès biuletenis, 2001, No. 1.

${ }^{20}$ Among the featured animals, there were 913 fish, 21 penguins, and 20 sea mammals (seals, sea lions and dolphins). There are 31 indoor aquaria. In 2011, the Museum contained the following exhibitions: sea fauna, the history of seafaring, the history of Kopgalis fortress, a dolphinarium, a fisherman's ethnographic farmstead, and a seashell and shellfish exhibition. Data from $<$ http://www.muziejai.lt/klaipeda/ juru_muziejus.htm.> [address visited on 1 Aug. 2011].

${ }^{21}$ G. Juodyte, 'Kaip radosi Jūrų muziejus: pradžiu pradžia', Vakaru ekspresas, 19 Feb. 2009. 
A combination of several factors made this illegal project possible. ${ }^{22}$ The legitimacy of the new museum was achieved through sophisticated tactics for avoiding the scrutiny of central planners. ${ }^{23}$ First, the Sea Museum was formalised as an extension of an already existing museum and not a new organisation: it was established as a branch of the Klaipeda Local History Museum. ${ }^{24}$ Second, the building for the Sea Museum was framed not as a new building for a new organisation, but as the restoration of a semi-destroyed fortress. Third, it was not the Supreme Council that decided on the need for an entertaining museum for Klaipeda residents, but the individual initiative of the chairman of Klaipeda City Council. Acting as a true entrepreneur, the chairperson provided the initial stimulus and administrative and personal patronage of the emergent museum, as he was able to involve top decision-makers of Soviet Lithuania in informal action nets when access to severely limited resources was necessary. Fourth, the geographical location was a good hiding place: the museum was constructed on a peninsula, a border zone that was patrolled by the military and physically separated from the city by a busy commercial and military seaport. Material structures could be hidden more easily than formal organisations. As long as the Sea Museum did not exist 'on paper' as a legal person with the staff and salary flows, it could be assembled materially. Finally, until the formal establishment of the Sea Museum in 1976, museum staff were instructed not to make any

${ }^{22}$ The Sea Museum was not the only large construction project that was 'legally illegal'. Even the construction of a new building for the Supreme Council in Vilnius was started without official approval of the Lithuanian SSR Politburo in 1976. The construction of this building was halted by Moscow as it imposed a ban on new administrative buildings. However, thanks to personal lobbying at the higher decisionmaking organ, the all-union Politburo in Moscow, construction was resumed and completed. A. Barkauskas, Laikmečio įkaitai (Vilnius, 2009), pp. 400-412.

${ }^{23}$ In this way it was advantageous for the museum builders not to translate their project into a formal language of inscription. As they were not transported through 'movable immobiles', material structures could be secretly erected. M. Callon, 'Some Elements of Sociology of Translation: Domestication of the Scallops and the Fishermen of St Brieux Bay', in: J. Law (ed), Power, Action and Belief: A New Sociology of Knowledge? (London, 1986), pp. 196-223.

${ }^{24}$ The Sea Museum was not unique in this respect. It was administratively easier to establish in fact new museums as branches of existing museums, for example, the highly popular Museum of Amber was created as a branch of the Lithuanian Art Museum. See E. Rindzevičiūte, 'Soviet Lithuanians, Amber and the "New Balts": Historical Narratives of National and Regional Identities in Lithuanian Museums, 1940-2009', Culture Unbound, Vol. 2010, pp. 665-694. 
public statements about the project and be especially cautious with journalists. $^{25}$

How does one write a history of an illegal construction that took place about forty years ago? The history of the Sea Museum has actually been described in numerous articles in the press. In addition, stories of the creation of the museum are presented in the published memoirs of important figures in the cultural policy of Soviet Lithuanian. The most important source here is the memoir by the director of the Sea Museum, A. Každailis (b. 1943). Educated as an historian at Vilnius University, Každailis is known not only as the director of the Sea Museum (1975-2002) but also as a writer of popular books about sea life and stories for children. His memoir is a sophisticated literary work, with a lot of attention to detail and rich ethnographic descriptions of organising, but also peppered with racist and sexist jokes.

Memoirs and internally produced institutional histories are usually biased towards emphasising the importance of the authors. However, this bias is also useful, as memoirs tend to detail personal networks and informal relations. Memoirs also describe events that happened 'back stage': the whole point of writing a memoir is to provide an alternative view to official institutional history, but, as Každailis made explicit, also to give an alternative explanation to the kind of history that can be reconstructed from documents. Finally, although the director's memoir is almost entirely dedicated to informal relations, the memoir also addressed the role played by formal organisations of administration and control, such as the Ministry of Culture of the Lithuanian SSR, Klaipèda City Council, the censorship organs (Glavlit) and the Committee of State Security (KGB). Thus, the memoirs form the basic material for my analysis. ${ }^{26}$

\section{The Beginning or How to Get Things Done When Nothing Works} From the abolition of national economic councils in 1964, the economy of Soviet Lithuania became increasingly centralised. The government was in charge of only 10 to 12 per cent of industrial enterprises

\footnotetext{
${ }^{25}$ Každailis, Smagios, p. 50.

${ }^{26}$ Further investigation is needed to establish moments when formal actions (legislation, decrees by the Minister of Culture and the City Council Chairman) were undertaken. This would entail a traditional archival study, which would possibly throw light over interesting questions, such as whether informal relations and especially action nets preceded or followed formal actions. It would also be interesting to find out whether any particular spheres could only get organised through formal actions. This study hinted at some such spheres, for example, deals with foreign currency.
} 
in the mid-1980s; the rest directly answered to branch ministries in Moscow. ${ }^{27}$ Nevertheless, the beginning of the construction of the Sea Museum demonstrates that Soviet formal restrictions and severe shortages could be relatively easily circumvented with some creative thought. In the 1960s-1980s, building cultural venues became a means for the expression of status for Soviet leaders at various levels. Although actively discouraged by the central administration in Moscow, such buildings were erected as signs of economic affluence and autonomy. Chairpersons of collective farms took pride in the construction of massive houses of culture; the head of the Planning Committee was proud of the Vilnius Academic Drama Theatre. ${ }^{28}$ The initial idea to create a sea aquarium in Klaipeda is attributed neither to marine scientists, nor to cultural sector professionals, but to a member of the formal Lithuanian Communist Party (LCP) government apparatus, the chairperson of the Klaipeda City Soviet Executive Committee, A. Žalys (1929-2006).

A member of the Soviet nomenclature, Žalys earned a good reputation, both among cultural workers and among other functionaries of the Lithuanian Communist Party. ${ }^{29}$ The inspiration for creation of a sea museum came to him during his 1968 holiday in the Crimea near the Black Sea, where he visited the Marine Aquarium Museum in Sevastopol, one of the oldest public aquaria in Europe, established in $1897 .^{30}$ When Žalys was appointed chairman of the Klaipeda City Council the next year, he took steps to establish a similar museum in Klaipéda.

The relation between centre and periphery was especially important in the case of Klaipeda. The city is situated on the Baltic Sea, in an area that historically belonged to Prussia and later the German empire. The Lithuanian Republic annexed the Klaipeda area in 1923, but in 1939 it was occupied by Nazi Germany. During the Second World War Klaipeda's population experienced dramatic changes: in 1939, the city had 51,000 inhabitants in 1939 , but only 3,000 by 1945 . After the war Klaipeda was populated by new settlers, many of whom came

${ }^{27}$ Lietuva 1940-1990: Okuopuotos Lietuvos istorija (Vilnius, 2005), p. 535.

${ }^{28}$ See L. Šepetys, Neprarastoji karta: siluetai ir spalvos (Vilnius, 2005), p. 136.

${ }^{29}$ The former Lithuanian SSR minister of culture retrospectively described Žalys as 'a master of quiet and subtle work. Unlike other heads of cities, he used to start a conversation about a construction project that was needed by the city or other important matter not with a discussion about finance or material matters, but from the attractiveness of the idea', Šepetys, Neprarastoji karta, pp. 6-7.

${ }^{30}$ V. Jakelaitis, Apgaulinga muzieju tyla (Kaunas, 1998), p. 57. 
from Russia ${ }^{31}$. The city bounced back quickly and had 48,500 inhabitants in 1950. Only 40 per cent, however, were Lithuanian-language speakers. $^{32}$

In this way, Klaipeda was a striking example of a boundary zone. The city witnessed massive population displacement. At the same time, Klaipeda was a hub of flows of material objects and people as it served as a commercial and military seaport. These flows were tightly regulated as they crossed the Iron Curtain: Klaipeda was on the Western border of the Soviet Union. The nearby picturesque $\mathrm{Cu}-$ ronian Spit, home to old fishermen's villages, holiday makers, and later the Sea Museum, was heavily patrolled by border guards and housed anti-nuclear missile bases.

Klaipeda, in this way, was a genuine Cold War playground and this thrill of being on the border was evident in Každailis' memoirs. The action nets in the creation of the Sea Museum could and did tie into 'big games', such as international travel through the Iron Curtain, high-tech technology or even high politics. Construction of a museum is traditionally regarded as an intellectual venture, but published descriptions of the construction of the Sea Museum have little to do with intellectual ambition. In contrast, these descriptions are plotted as tales of manly games and challenging adventures. It seems that it was not ideas, but daring actions, which mattered most in this case of museum building.

The creation of new museums was not strictly centralised in the Soviet Union. Although most large museums were established by a decree of the Minister of Culture, smaller museums could be established by other administrative units, for example, trade unions or local authorities. Universities and the Soviet Academy of Science were also active creators of important museums. When the Sea Museum was finally registered as a separate organisation, it was subordinated to the Klaipeda City Council. The council chairperson Žalys himself actively supervised practical aspects of both the construction of the building and formation of exhibitions. Given the ambition, scale and complexity of the Sea Museum, it does, however, stand out as an

${ }^{31}$ V. Safronovas, 'Lietuviškosios praeities aktualizavimas kaip tapatumo orientacijos raiška pokario Klaipėdoje', Lietuvos istorijos metraštis. 2007 metai, 2, 2008, pp. 60-61.

${ }^{32}$ The percentage of Lithuanians eventually increased: in 1959 Klaipeda's population was 89,900 of which 56.6 per cent were Lithuanians. Lietuva 1940-1990, pp. 23, 390, 395-396. 
oddity in this otherwise relatively pluralist institutional context. Indeed, as mentioned earlier, it was the size, cost and complexity which would have made this grand project impossible to implement through central planning. The building dedicated to science and leisure could not be defended against the higher priorities of industrial and housing development.

The vision of the Sea Museum could be understood as an entrepreneurial project that was first driven by the City Council chairman, who later delegated the museum to a small team of professionals. In 1969 the city architect P. Lape, who was the head of the Klaipeda branch of the City Construction and Planning Institute (1965-1981), was asked by Žalys to make a preliminary design of the Sea Museum. Cost calculations revealed, however, that it was an expensive project, which meant that, in principle, approval had to be sought from Moscow. ${ }^{33}$ However, the city chairman started with Lithuanian SSR leaders but not with Moscow; this is the first step where knotting an action net requires a connection to formal organisations.

The first discussion about funding was informal, but conducted in the context of a formal organisation. During a break at a meeting at the Trade Union Palace in Vilnius, 1971, Žalys approached P. Kulvecas, a deputy Chairman of the Lithuanian Ministers' Council, and A. Brazauskas, first deputy head of the country's State Planning Committee. Indeed, Kulvecas was already informed about the envisioned project, and having also seen a sea aquarium abroad supported Žalys's idea. Brazauskas immediately asked about the requirements. At that time, the costs of construction work was estimated at 300,000 roubles, a sum that Brazauskas considered not to be too large, so the money was allocated. As Žalys put it later, 'of course, everything ended up costing fifty times more, but that was our own business. ... I knew from past experience that grand projects should be started incrementally, it would not work to ask for everything at once'. ${ }^{34}$ In this respect, the construction of the Sea Museum was not different from other Soviet Lithuanian flagship projects, such as Trakai Castle and the Vilnius Opera and Ballet Theatre. Intentionally diminished budgets for these

${ }^{33}$ Although the Ministry of Culture had its own budget for capital investments which involved construction works, any more ambitious project required much more resources than the Ministry could offer. The contribution of the Ministry of Culture was made at a later stage, for example, the museums' exhibition displays were produced at Daile trust.

${ }^{34}$ Jakelaitis, Apgaulinga, pp. 59-60. 
projects were presented in order to avoid opposition, and they were approved. ${ }^{35}$ The most important thing was to start construction and, in this way, to literally materialise the project. ${ }^{36}$

After this spoken promise of funding was obtained, the administrative structure of the museum had to be created. As mentioned above, to keep things quiet, rather than establishing a new organisation, a branch of an existing organisation was established. In 1971, A. Každailis was appointed head of the Sea Department and took charge of further organisation of the Sea Museum. ${ }^{37}$ In July 1971, the Sea Department was opened to visitors and building work at the fortress started in 1974. ${ }^{38}$ When the Sea Museum was transformed from a branch into an independent organisation in 1976, the central authorities in Moscow were still not informed about the existence of the museum in Klaipeda. ${ }^{39}$

Creation and Activation of Technical Systems Každailis's memoirs contain a detail-rich account of various material obstacles, which could only be overcome informally. In what follows, I will discuss several salient examples, which aptly reveal the interplay between action nets, networks and formal structures. We have to start by emphasising that the envisioned Sea Museum was literally a boundary object. The museum was to be situated in a fragile natural environment of sand dunes and a nearby busy highly securitised seaport. Furthermore, the museum was to contain technical systems, which were

${ }^{35}$ For instance, the project for the Opera and Ballet Theatre estimated the cost at two million roubles although it was known by the minister of culture that the true cost was over 14 million roubles. Additional funds were raised from savings elsewhere and sales of game meat. The exceeding of budgets was not harshly penalised by the Moscow authorities: the LSSR Minister of Culture only received a written notice. The architect, however, was awarded a state prize. Šepetys, Neprarastoji karta, pp. 130, 132 .

${ }^{36}$ Later on, the chairman of city council approved various schemes of doing illegal things legally. A typical trick was to frame the construction of a new building as 'renovation'. For example, a fin-de-siècle wooden villa in Kopgalis was 'renovated', that is, demolished, and a replica of a wooden thatched fisherman's cottage was built instead. Jakelaitis, Saulei leidžiantis - toks buvimas drauge, II knyga (Vilnius, 2002), p. 23.

${ }^{37}$ Každailis worked at the Local History Museum from 1965. G. Juodyte, 'Kaip radosi Jūrų muziejus: pradžių pradžia', Vakaru ekspresas, 19 Feb. 2009.

${ }^{38}$ The Sea Department was situated in a little house in central Klaipėda. Even this process of installing a new museum proved to be challenging: on a daily basis the director had to chase an unreliable building contractor to make sure that workers would show up at the site. Každailis, Smagios, p. 11.

${ }^{39}$ Ibid., pp. 23-25. 
never before built in Lithuania: one building was to house about thirty aquaria with different types of water.

The selected site was that of Neringa Fortress in Kopgalis, built in 1865-1871. Abandoned in the 1920s, the fortress was used by the Nazis during the Second World War, and they destroyed large parts of it when retreating. By the end of the $1960 \mathrm{~s}$, there were plans to build commercial warehouses on the site; however, inspired by the city architect Lape, the chairperson Žalys made sure that the fortress would be preserved, reconstructed and adjusted to the Sea Museum. ${ }^{40}$ Thanks to a lucky coincidence, during a study trip in East Germany Každailis found the original designs of the fortress in the Merseburg archives. ${ }^{41}$ A couple of heritage specialists were hired to supervise the reconstruction of Neringa Fortress. Reconstruction work started in 1972, and was finished in $1979 .{ }^{42}$

The problem was that the fortress mound contained many undetonated explosives, which were removed in 1973 and 1974 and later in 1977. ${ }^{43}$ The director recalled that although the Soviet military claimed that the explosives were removed, deeper digging into the soil kept uncovering masses of cannon balls and anti-aircraft machine gun bullets. The action net needed to be extended: the military was called in again. Nevertheless, the danger of hidden explosives remained. The director recounted that the only precaution was to cover the excavator's windscreen with a steel sheet, surely insufficient in case of explosion. The driver, however, would have a drink of fortified wine and continue his work. ${ }^{44}$

${ }^{40}$ The architect Lape recalled that in 1969 Žalys initially wanted to establish the Sea Museum in Palanga, a small town that was also a popular sea resort, about 26 kilometres from Klaipeda. However, the architect contested this idea because visitors come to Palanga only during summer and the small town is hardly visited at all during the rest of the year. Lape suggested the fortress at Kopgalis instead. It is significant that recalling this conversation Lape emphasised that this exchange of ideas took place in an informal environment, as Lape and Žalys walked out from a restaurant for a breath of fresh air. Jakelaitis, Apgaulinga, p. 57; J. Rakauskaite, 'Petras Lapé: "Vedžiau gražiausią moteri mieste", Vakaru ekspresas 20 Jan. 2009.

${ }^{41}$ Jakelaitis, Apgaulinga, p. 60.

${ }^{42}$ The reconstruction design was prepared by architects P. Lapè, the head of the Klaipeda City Construction Institute, V. Šliogeris and L. Šliogerienè of the Institute for Conservation of Monuments and technical designer T. Tubis.

${ }^{43}$ Každailis, 'Netolimos praeities prisiminimai iš Kopgalio tvirtovès', Lietuvos muziejai, 2004, No. 2-3.

${ }^{44} \mathrm{Little}$ attention was paid to health and safety on the construction site. The director romanticised these daring workers and described them as patriotic heroes: they 
The construction of aquaria needed another extension of the action nets. The aquaria were to be constructed by local innovators, who had limited opportunities to draw on international knowledge transfer. Sea aquaria existed in the Soviet Union, for instance in Sevastopol and Moscow, but as the construction of the museum was formally illegal the architect could not rely on official collaboration with his Soviet or other East European counterparts. ${ }^{45}$ In Soviet Lithuania, little was known about even those sea aquaria in the Eastern bloc. ${ }^{46}$ Being an architect whose professional experience mainly involved urban architecture and artistic design, Lapé did not have personal contacts with aquarium designers. It is rather telling that Lape chose to use his personal network and asked his brother who lived in the USA to send him examples of any American sea aquaria. Corresponding with émigrés was a sensitive matter: all correspondence with the West was screened by the KGB; however, the architect chose this personal channel rather than turning to formal search for expertise. The architect's brother sent a leaflet about the New England Aquarium, which had just opened in Boston in 1969. The Lithuanian architect immediately spotted a worryingly large building for water filters. No such huge industrial structures were to be thought about in the fragile natural environment of the Curonian Spit. Lape had little choice but to invent a filter that would be less visible. His solution was to pump water from the Baltic Sea, which was then filtered through natural sand into a special reservoir and subsequently adjusted up to the required level of salination. Other practical problems that demanded innovation were pipes for transporting seawater and reinforced concrete structures to hold the aquarium. At that time, only zinc-covered pipes were used in Lithuania and, being highly corrosive, they were unfit for the purpose. Lapé and the technical engineer T. Tubis insisted on

worked 'not for the Soviet regime, not for the party and the government, but for themselves, their own city and people'. Každailis, Smagios, pp. 18, 66.

${ }^{45}$ Only in 1976 did the city council chairman finally organise a trip for the Sea Museum staff to the Marine Aquarium in Gdynia, ibid., p. 69.

${ }^{46}$ The director retrospectively emphasised that a lot of knowledge and technology transfer between Sea Aquarium in Gdynia and Klaipèda took place during informal parties in Gdansk, Poland. During one such party, for example, Každailis got to know from Polish colleagues about the existence of East German oil Polyglykole-4000 that was used to conserve wood which spent a long time in water. This product was obtained and used to conserve anchors, ibid., p. 70. 
plastic pipes, which in turn demanded many trips to plastic factories in other Soviet republics. ${ }^{47}$

The biggest trouble proved to be the aquarium itself. It required 176 cubic meters of concrete and continuous work. Given the notorious unreliability of building contractors, the aquarium was the most complicated management project. Typical reinforced concrete structures were square, but this one had to be spherical. The designs were made by Lapé and Tubis. The technology of casting was specially developed by the Second Reinforced Concrete Factory in Klaipeda. Non-typical production, as a rule required a lot of additional effort and Soviet concrete factories were already overloaded with planned commissions. A journalist recalled that a particularly strong incentive scheme, namely, a license to buy a private car, was used to coopt factory engineers to take on this disruptive order. Although the factory was directly subordinated to the central all-union ministry, it dared to use reserve metal funds. ${ }^{48}$ In November 1974, the first reinforced concrete structures were put in place. However, neither strikingly generous 'bribing' with cars nor personal on-site supervision of the contractors by the chairman of the City Council were sufficient to assure high quality. The concrete foundation was cast unevenly and leaked: hardly a surprise for notoriously unreliable Soviet industries. ${ }^{49}$ It seems that informal relations did not necessarily guarantee better quality than formal relations did.

Various materials were needed that were not produced within Lithuania, and therefore deals that required hard foreign currency were necessary. It is at this point that formal relations had to be activated, because hard currency deals could not be done by local actors. For instance, the acquisition of French glass for illuminators required the co-opting of central organs: the city council chairperson convinced the head of the Lithuanian SSR Planning Committee, A. Drobnys, to approach the all-union Gosplan with a request to purchase that type of foreign glass. ${ }^{50}$ The co-option of the top decision maker was a prolonged process. First, the museum director had to prove that no Soviet factory could manufacture the required type of glass. This took a trip

\footnotetext{
${ }^{47}$ G. Juodytè, 'Kaip radosi Jūru muziejus: "kosminès technologijos"”, Vakaru ekspresas, 3 Apr. 2009.

${ }^{48}$ G. Juodyte, 'Kaip radosi Jūrų muziejus: naujų žemių paieškos', Vakaru ekspresas, 22 May 2009.

${ }^{49}$ Každailis, Smagios, pp.19, 25-27.

${ }^{50}$ Ibid., p. 28.
} 
to the Avtosteklo factory that made glass for automobiles in Konstantinovka, Ukraine, supported by Lithuanian chocolates for secretaries and vodka for senior managers. Eventually, Drobnys applied to the central authorities in Moscow for the permission to buy French glass. So expensive was this purchased glass, that, being afraid to break it, contractors refused to put it into illuminators. It was the museum staff who placed the precious glass into frames, a daring job that resulted in continuous leakages. ${ }^{51}$ In the case of aquarium glass, formal structures were used to obtain funding, but informal and amateur work was used to put the material in place.

It is difficult to overestimate the significance of material objects and settings as knitting and knotting of action nets in the building of the Sea Museum. Explosives, concrete casts, plastic pipes and thick glass: all these non-human actants required human actors to mobilise existing networks or forge new action nets. These action nets spread well beyond the formal structure of the museum as they came to involve the military, industrial plants and, last but not least, the country's economic planners. More often than not informal relations were a rule when establishing an action net with a very different sector. Furthermore, additional non-human actants, such as chocolates for secretaries, spirit for workers and cars for engineers, played an important role in sustaining the action nets. Even more important was the agency of non-humans in the assembling of the Sea Museum's collections.

\section{Men at the Museum and at Sea: Obtaining and Securing Bound-} ary Objects In one important respect, the Sea Museum seems to be similar to many other new museums, which were created in Soviet, and post-Soviet Lithuania: it lacked collections and exhibits. ${ }^{52}$ The Sea Museum staff searched for exhibits, both things and living creatures, in shipyards and old fishermen's cottages, but also in the Caribbean, the Atlantic, the White Sea and the Sea of Japan. I will now show how collecting was organised via formal and informal relations. In this process, the collected items were actively considered as boundary objects: it was their simultaneous relevance to different worlds, which made the forging of action nets possible. Finally, I will

${ }^{51}$ Ibid., pp. 28-29.

${ }^{52}$ E. Rindzevičiūtè, 'Institutional Entrepreneurs of a Difficult Past: Organisation of New Knowledge Regimes in Post-Soviet Lithuanian Museums', European Studies (forthcoming). 
show that the director and other staff used collecting as a means to draw new boundaries, to construct themselves as special actors. Being in charge of an extraordinary task, the museum staff narrated their work practices in a way that could not be further distanced from the traditional role of a museum worker. It was not the meticulous and intellectualised practice of gathering and cataloguing, but the highly gregarious life of a group of men who daringly travelled across the boundaries of institutions, industries and states.

The first steps in collecting were taken by the director Každailis, who set to gather things that related to the history of seafaring. The director recalled that the first help was provided by captain V. Pakalniškis, who provided him with access to a wide range of sites and organisations at Klaipeda seaport. Pakalniškis's assistance involved formal mediation. As Každailis put it, 'I used to enter through doors with a letter and leave through gates with exhibits' (mainly relating to industrial fishing). ${ }^{53}$ To start with, the director visited old and abandoned ships and collected various things, such as anchors, trailing parts, but also various navigation instruments and things from everyday life on board the ship. As the director put it, "we would not disregard even a shelf for binoculars, navigation log books and guard journals, because it was also of the sea and not of the land'. ${ }^{54} \mathrm{Al}-$ though the director graduated as a historian, his memoirs do not hint at any consistent scientific, cultural or aesthetic rationale behind the accumulation of the collection. Quite the opposite, he was uncertain about the displays: 'Uncertainty embraced my little room, not much bigger than a Khruschevian bedroom, on the first floor of a house on 14 Mantas Street. I proudly called that room a hall of marine nature exhibition, but this did not make it clear for me what was to be exhibited there' ${ }^{55}$ At the same time, the director detailed his thrill at finding old objects and the excitement of saving them from extinction. It can be suggested that the absence of an explicit and consistent rationale was due to the ad hoc organisation of the museum, which relied on action nets, but also networks. At a later stage, a more formalised tactic for the formation of the collection was assumed and undertaken by the new museum's research staff.

\footnotetext{
${ }^{53}$ Každailis, Smagios, p. 11.

${ }^{54}$ Ibid., pp. 11-13.

${ }^{55}$ Ibid., p. 13.
} 
From the very beginning personal networks proved to be crucial. Through a widely known distinguished biology teacher, the director got into contact with a helmsman, F. Rimkevičius, who was also a keen seashell collector. ${ }^{56}$ The seaman donated his collection to the museum. ${ }^{57}$ The collection was further developed by the newly employed professionals. An in-house taxidermist was needed to prepare exhibits and this role was filled in by A. Laurinavičius from the Kaunas Zoological Museum. The organisation of the marine fauna and flora section needed a biologist. Formal channels were used to get access to good scientists: the director approached several departments at the Faculty of Natural Sciences at Vilnius University. Candidatures of two men (A. Stankevičius and E. Buivydas) were suggested and both were subsequently employed at the museum in 1974. The formal staff structure was determined by the ministry, but the actual staffing was initiated by the museum's director, who used both personal contacts and the help of higher education organisations to find good collaborators.

The museum creators followed the formal organisational rules of museum building, which were set by the ministries of Culture and Construction. However, in order to preserve their image of 'reliable partners', they decoupled their everyday informal practices from this rational organisation. The organisation of the Sea Museum was often portrayed by its creators not as formalised, bureaucratic (probably feminine) work, but as an exciting activity of confronting serious dangers (illegal construction, hidden explosives), engaging in adventures (sea faring) and participating in informal masculine interactions (drinking alcohol in sand dunes, in the museum and on the building site). ${ }^{58}$ In the director's story about the museum building, women appear only in passing, although one woman was part of the core team: L. Šliogerienè, an architect, heritage preservation specialist and designer of displays. The other women were either secretaries with whom the museum director flirted to get access to their bosses, or

${ }^{56} \mathrm{Ibid}$.

${ }^{57}$ The display of seashells collapsed shortly before the opening (11 July 1971): the director recalled that an important exhibit, an Australian trumpet shell, was smashed in front of the collector himself.

${ }^{58}$ One man was employed as a treasurer of exhibit funds, and among his formal tasks was the production of inventory lists. This formal role, clearly, did not match well with the ideals of masculinity that seemed to govern the Sea Museum. The director retrospectively noted that it was a shame that 'a fit, active man had to deal with boring papers'. Každailis, Smagios, p. 23. 
tour guides, whom the director decided to dress in claret-coloured uniforms against their protests. ${ }^{59}$

Perhaps the most romanticised among retrospective accounts about the organisation of the Sea Museum are stories about exhibit hunts (a proper male activity). Exhibition plans, devised by the biologist Stankevičius, came before exhibits. The museum employees had to cross many boundaries to get access to them. Firstly, collecting exhibits required crossing the Iron Curtain: in 1975, the director and one biologist joined a fishing fleet on a trip to the Atlantic. Secondly, in order to be able to do that, both the director and the biologist had to cross the boundaries of their organisational affiliations: they became actually employees of the ship's crew affiliated as 'lecturers'. In order to join the crew, the museum workers had to obtain a special sailor's pass, which involved close screening by the KGB. ${ }^{60}$ Thirdly, the two museum biologists had to obtain sea diver certificates, for which they trained in the Kaliningrad area. The director and one of the biologists eventually sailed to Mauritania, where they changed ships and picked out their exhibits from fishing nets. The researchers picked out many marine creatures, which were regarded as 'rubbish' by sailors, such as sea stars, jellyfish, crayfish and seashells. ${ }^{61}$ The catch was deep frozen, and brought back to Klaipeda where the taxidermist stabilised the 'rubbish' into lasting exhibits. The first fieldwork lasted for about three months; the same year the biologist embarked on a second trip

${ }^{59}$ For example, the director described his travels through offices in pursuing agreements to take on a non-planned order: 'Having received the order papers, I visited four senior managers to obtain their signatures to confirm the confirmation of my order; at every door I waited for an hour or so for a meeting to finish, and while waiting I did not waste my time but told stories about the family lives of seals and penguins to plump and delicious secretaries', ibid., p. 78.

${ }^{60}$ Ibid., p. $80-81$.

${ }^{61}$ The director recalled: 'We had a lot of work on this boat because frequently the catch contained only molluscs. Then the men cursed the fate of a fisherman and the crew of a boat that searches for fish... Then we two museum workers kept our mouths shut, god forgive not to show our pleasure at their misfortune, especially when instead of boring Indian volutes we find more rare shell species, such as ... Murex, Triturus, so we would like to sing from happiness'. Another difficulty that museum work presented on the sailing ship was shell preservation. Molluscs were piled in the ship's chimney and left for a few days to die and rot in the heat. A side effect of this procedure, which made it easier to clean the shells, was an awful stench on deck. However, the sailors were generous with their help in collecting molluscs and cleaning shells, ibid., p. 99. 
with fishermen. Thus, the action net that may be called 'construction of the Sea Aquarium' has been seriously, though temporarily extended to include actions very distant from its core.

This extension of an action net was not easy at all. It was relatively easy to arrange places for museum workers on Lithuanian fishing boats through local contacts with the seaport and city council heads. However, the destinations of these boats were limited and large fishing boats could not be used for lengthier stays on one site and diving. It was unthinkable that the Sea Museum could have its own research boat. In order to complete the exhibition plans, the biologists needed to get on a boat that was dedicated to marine research. The access was not arranged either through the Lithuanian SSR or all-union Ministry of Culture. It was conceivable that the Academy of Sciences or the Fishing Ministry could come to aid to the new museum, however, neither was contacted. Instead, the biologist Stankevičius recounted that the action nets were knotted through precarious personal contacts. Furthermore, non-human actors were vital in this original extension of the action net.

Stankevičius was at a conference on biology in Leningrad, where he overheard the director of the Institute of Marine Biology in Vladivostok (IMB), A. Zhirmunski (1921-2000) complaining to his colleagues that he could not get pieces of amber to clean needles used for acupuncture. Coming from 'a country of amber', ${ }^{62}$ the Lithuanian biologist was brave enough to cut in the conversation among strangers and to offer amber to Zhirmunski. The IMB director was grateful and responded to this favour by sending a stack of literature about the work of IMB to the Sea Museum. It was from these publications that the biologist discovered that IMB was preparing for a large expedition with its own ship. Behaving boldly, Stankevičius asked if he could join them. Zhirmunski was again positive and asked for a favour in return: the Klaipeda museum staff should help to receive the required containers and meet the expedition participants. ${ }^{63}$

The biologist embarked the IMB ship that was to sail around half the world in 1976. The first expedition focused on the Sea of Japan. Next year Stankevičius was again lucky to be accepted on the IMB

\footnotetext{
${ }^{62}$ See Rindzevičiūte, 'Soviet Lithuanians, Amber and the "New Balts" ...'

${ }^{63}$ G. Juodytè, 'Kaip radosi Jūrų muziejus: eksponatų “žvejyba”, Vakaru ekspresas, 11 Jul. 2009.
} 
ship to sail to the White Sea. It is significant that Stankevičius retrospectively observed that "he travelled were he could "hang on" and not where he would have really wanted to go' ${ }^{64}$ Although plans for the collection were prepared beforehand, the actual collecting took place sporadically rather than systematically.

Live exhibits were also transported through the Iron Curtain. Again, the city council chairperson made sure that hard currency was available to purchase crested penguins from a Dutch company in 1977. These penguins, naturally, were flown to Vilnius via Moscow. In 1978, several grey seals were caught by an Estonian collective farm and transported to the Sea Museum. Later on, the Sea Museum gave away young seals to Polish, Czechoslovak and even Japanese zoos. In 1980, the museum biologist Buivydas travelled to the Caspian Sea to catch and bring back live sturgeons. This trip was also initiated through informal connections, which interestingly failed. A man from Makhachkala, Dagestan, visited the Sea Museum and promised his full-fledged support to the museum biologists in catching sturgeons. However, when the Sea Museum team actually arrived at Makhachkala, the enthusiastic helper, who was kept anonymous in the director's memoirs, failed to provide them with any assistance. The informal action net proved to be unsuccessful in this case. However, while staying in Makhachkala the biologist Buivydas accidentally met his former university colleagues from Vilnius who were there on a research mission. The scientific expedition helped Buivydas to catch sturgeons and ensured that the fish were transported alive by air to Klaipeda. This mission succeeded thanks to a lucky coincidence and mobilisation of a pre-existing personal network that was well anchored to a formal organisation. ${ }^{65}$

The informal knitting and knotting of action nets deemed necessary did not end with the completion of the Sea Museum. Indeed, both the staff and the site of the Museum were used to extend further this informal action net. As the former Lithuanian SSR Minister of Culture noted, 'for the heads of the Klaipeda City Council, summer season was a good time to harvest useful agreements' ${ }^{66}$ For instance, the director recalled that the museum's leadership was summoned to organise fishing tours and drinks for Drobnys, the head of the LSSR

\footnotetext{
${ }^{64}$ Ibid.

${ }^{65}$ Každailis, Smagios, 108, pp. 112-114.

${ }^{66}$ L. Šepetys, Neprarastoji karta, p. 155.
} 
Plan Institute. ${ }^{67}$ Indeed, just before the official opening of the Sea Museum in 1979, the chairperson of Klaipeda City Council asked the museum workers to arrange a reception for V. Grishin, an influential member of the Politburo in Moscow, known for helping to oust Khruschev in 1964. Grishin came with his family on a private holiday trip to the Lithuanian seaside. This meant that building work had to be completed one week earlier and to achieve that even the research staff undertook various building tasks. ${ }^{68}$ By building the Sea Museum, its director, in other words, also constructed his own personality as that of an adventurous male who came to enjoy a substantial social authority as a fixer of favours.

In 1980-1985, open-air swimming pools were constructed for seals and sea lions and a performance stage was installed. In 1986-1994, a dolphinarium was created.$^{69}$ Few would argue that the existence of the Sea Museum did not constitute a striking and unusually entertaining contribution to the otherwise rather limited options for passing non-ideological leisure time for ordinary Soviet citizens. Implemented largely through informal relations, which often included blat, the Sea Museum arguably contributed to the public good. Perhaps one of most significant stabilising effects of this construction was the cementing of local pride and identity among Klaipeda's citizens, many of whom could boast of having taken part, formally or informally, in this fascinating project. ${ }^{70}$

Conclusion As Lindberg and Czarniawska acutely point out 'formal organizations arose out of action nets, they are part of such action nets and are host to many others' ${ }^{71}$ In the Soviet context action nets,

${ }^{67}$ The importance of such informal assistance was huge. After the fishing tour, the director recalled that he promised to Drobnys to smoke the fish overnight so that he could bring this impressive catch with him to Vilnius. However, a museum worker who was in charge of smoking the fish got too drunk and next morning Drobnys found a smelly boat with a catch, which was clearly off. The chairperson of the Klaipeda City Council was particularly unhappy about this example of poor management and complained to A. Každailis that he lost his face in front of Drobnys: 'How will you be able to ask for limits for construction works and funds for materials? ... Comrade Drobnys will say, how are you going to build a dolphinarium if you are not able to organise the simplest thing?' Každailis, Smagios, p. 172.

${ }^{68}$ Ibid., pp.129-130.

${ }^{69}<$ http://www.muziejai.lt/klaipeda/juru_muziejus.htm.> [address visited on 1 Aug. 2011].

${ }^{70}$ A. Každailis, Smagios.

${ }^{71}$ Lindberg and Czarniawska, 'Knotting the Action Net', p. 293. 
particularly those that relied on informal contacts were studied first and foremost as a manifestation of the negative and corrupt behaviour of Soviet actors. The informality of Soviet administration, according to Garcelon, resulted in the emergence of an estate of 'rentseeking managers and administrators of the nomenklatura rank'. ${ }^{72}$ Similarly, the 'culture of informality' in Eastern Europe was identified with corruption. Informal relations, from this point of view, were explained as a vice that resulted from dysfunctional Soviet formal organisations. $^{73}$

However, it is debatable whether it is possible at all to pinpoint a purely Soviet or state socialist mode of organising. ${ }^{74}$ If formal and informal modes of organising were not sufficiently unique to differentiate Soviet or authoritarian and Western or liberal democratic regimes, what do we actually do when we label things as 'Soviet' or call for 'de-Sovietisation'? Informality can be regarded as a universal way to get things done in spite of formal organisations.

The practices of constructing the Sea Museum in Klaipeda had nothing to do with the implementation of a centrally set directive. On the contrary, these practices were essentially improvisations that drew on ad hoc association between actions requiring the involvement of human and non-human actants. New connections were often triggered by the demands of material settings, such as the building of the aquarium and acquisition of exhibits. Non-human actors demonstrated a good deal of agency: buildings, fish, technical systems, performed as boundary objects, which simultaneously inhabited many different worlds: that of seamen, of museum builders, of municipality administrators and also the world of Lithuanian SSR economic planners.

${ }^{72} \mathrm{M}$. Garcelon, 'The Estate of Change: The Specialist Rebellion and the Democratic Movement in Moscow, 1989-1991', Theory and Society, 26, (1997), p. 43.

${ }^{73}$ Mainly in Ledeneva, How Russia Really Works; and Grødeland "'Red Mobs".

${ }^{74}$ Despite the wide use of the adjective 'Soviet', there is little debate about its meaning. Existing writings suggest that the word 'Soviet' is commonly used in a nominal sense: to designate things and practices that were located in the Soviet Union. See, for instance, T. Lahusen and P.H. Solomon Jr., What Is Soviet Now? Identities, Legacies, Memories (Berlin, 2008). However, as I pointed out elsewhere, the word 'Soviet' is fundamentally a political term: the meaning of 'Soviet' is constructed retrospectively and selectively, usually in relation to 'de-Sovietisation' or attempts to remove certain things, institutions, individual persons or practices. See E. Rindzevičiute, 'From Authoritarian to Democratic Cultural Policy: Making Sense of De-Sovietisation in Lithuania after 1990', Nordisk kulturpolitisk tidskrift, 12, (2009), pp. 191-221. 
The networks and action nets were hybrid. They often derived their power and stability from loose couplings to formal organisations. Such action nets could then cut across the administrative divides, mix up 'below' with 'above', and avoid or cunningly ameliorate the influence of central units. For example, the director's memoir listed the great many ways in which the Sea Museum defended itself from external evaluations by journalists and auditors. Formal organisation of the Sea Museum was loosely coupled with the Lithuanian Ministry of Culture and Klaipeda City Council. Formal façades, such as descriptions of the roles of the staff and official functions of the organisation, which were meant to generate legitimacy in the institutional environment, were decoupled from the actual practices of the staff. ${ }^{75}$ Officially invisible, an action net can perform and not lose its face, as it has none. Even if the Museum has eventually become a formal organisation, it was nevertheless from the start only a department, not a separate organisation. Further, things that were not put on paper could not be easily circulated and scrutinised in other locations. The formal organisation was the most vulnerable when exposed to the scrutiny of central government. On the other hand, the managers of the museum were particularly vulnerable vis-à-vis building contractors, who had a monopoly on the material structure of the museum and could be supervised only on the site.

The construction of the museum was therefore decoupled from the centralised planning process. However, this does not mean that the Sea Museum was not subjected to other types of control. Indeed, the museum dealt with censorship mechanisms on a daily basis. For example, even printing seashells' labels had to be approved by Glavlit. The head of the exhibitions' plans requested the introduction a political dimension to the marine fauna exhibition, that is, to acknowledge the importance of the Soviet Union. ${ }^{76}$ Finally, the director also recalled visits of KGB agents who requested information on his staff.

Did this decoupling undermine central planning? According to Meyer and Rowan, not necessarily so. Decoupling and lack of accountability of the museum building could be understood as a symptom of the high institutionalisation of central planning: 'institution-

${ }^{75}$ Meyer and Rowan, 'Institutionalized organizations', pp. 357-358.

${ }^{76}$ An electronic display of the Soviet Union as a sea state was produced and manufactured in a secret post-code factory. Každailis, Smagios, p. 134. 
alized organizations protect their formal structure from evaluation based on technical performance: inspection, evaluation, and control of activities are minimized, and coordination, interdependence, and mutual adjustments among structural units are handled informally'. ${ }^{77}$ Indeed, it is thanks to decoupling that the appearance of working formal structures is maintained. Once completed, the Sea Museum quickly became a favourite setting for formal and informal visits of the members of the central government. Despite its illegal origin, a successful museum could be used to legitimise the image of a well-functioning Soviet state. The Sea Museum was made possible by and thrived on decoupling from the centralised formal planning process. Having proved to be a successful organisation, however, the Sea Museum, gave legitimacy to its wider institutional environment, as the shortcomings and inefficiencies were hidden from the public eye.

The Sea Museum also introduced a new cohesion to the city of Klaipeda, a place that had suffered massive destruction and overhaul of its population. The construction of the Sea Museum relied on diverse actors. The result was not just a building and exhibition displays, but also a new sense of communality. Many of Klaipeda's residents could relate their life stories to the construction of the museum. The militarised zone of the Curonian Spit was redefined as a popular site for leisure activities.

It is the productive role of informality in the processes of organising that is highlighted in this article. The case of the Sea Museum reveals that belonging to formal organisations was an important resource for actors who engaged in action nets that went beyond the boundaries of their formal organisations. In turn, the successful functioning of formal organisations often depended on informal relations, both within and without. To be sure, once the opposition between formal organisation and informal relations is abandoned, we have to leave the traditional sociological apparatus that juxtaposes the (formal) state and the (informal) society. The new language of organisation sociology, which emphasises relational and heterogeneous organising in which formal organisations rely on informal action nets and networks, may give new and important insights into Soviet realities.

\footnotetext{
${ }^{77}$ Meyer and Rowan, 'Institutionalized organizations', p. 357.
} 
Author Details

Egle Rindzevičiūte, $\mathrm{PhD}$ in Culture Studies, is a post-doctoral researcher at the Gothenburg Research Institute, the University of Gothenburg and the Department for Studies of Social Change and Culture (Tema Q) at Linköping University. Her research interests cover the history of material and intellectual technologies of governance and production of knowledge regimes in cultural sector. She is the author of a monograph Constructing Soviet Cultural Policy: Cybernetics and Governance in Lithuania After World War II (2008) and several articles in peer review journals and books, most recently 'Internal Transfer of Cybernetics and Informality in the Soviet Union: The Case of Lithuania' (Reassessing Cold War Europe, eds. Sari Autio-Sarasmo and Katalin Miklossy, 2011).

Address: Gothenburg Research Institute School of Business, Economics and Law University of Gothenburg, Box 603, SE 40530 Gothenburg, Sweden.

Email: Egle.Rindzeviciute@gri.gu.se

\section{FORMALIOS ORGANIZACIJOS IR NEFORMALŪS SANTYKIAI \\ SOVIETINĖJE LIETUVOJE: VEIKSMŲ IR VEIKĖJŲ TINKLAI BEI RIBINIAI OBJEKTAI KURIANT LIETUVOS JŪRŲ MUZIEJŲ}

Santrauka

\section{EGLE RINDZEVIČIŪTÉ}

Vakarietiškoje organizacijų sociologijoje paplitęs požiūris, kad formalių organizacijų sẻkmingas funkcionavimas dažnai labai priklauso nuo neformalių santykių, gali duoti įdomių rezultatų perinterpretuojant sovietinès sistemos istoriją. Šia studija siekiama prisidèti prie socialinių istorinių organizavimo ir valdymo sovietinio režimo šalyse tyrimų. Pagrindinis analizès objektas yra Jūrų muziejaus statyba Klaipėdoje nuo 1960 m. iki 1980 m. Jūrų muziejaus kūrimas buvo itin ambicingas projektas, kuriam igyvendinti reikèjo didelių kapitalo investicijų, retų užsienietišku medžiagu ir bendradarbiavimo tarp daugelio skirtingų sektorių (sovietinès armijos, paveldo apsaugos, jūrų uosto valdybos, žvejybos laivų ir zoologijos sodų bei jūros akvariumų Rytų bloko šalyse). Jūrų muziejaus statybai reikèjo ir kūrybiškų vietinių inovacijų projektuojant akvariumų sistemą. Nepaisant ịspūdingų mastelių, šis projektas buvo formaliai nelegalus: tuo metu visos sajungos mastu galiojo griežti apribojimai vadinamiemsiems ,žiūrovams skirtiems pastatams”.

Straipsnyje analizuojami formalių ir neformalių santykių vaidmenys konstruojant Jūrų muziejų kaip viešojo gėrio projektą. Turint omenyje, kad statant Jūrų muziejų, nebuvo paisoma centrinio planavimo prioritetu, kyla klausimas dèl politinio šitos statybos pobūdžio: ar galima vertinti Jūrų muziejų kaip antisovietinį arba asovietini 
projektą? Straipsnyje pateikta analizė parodo, kad būtų klaidinga mėginti atsakyti i šs klausimą remiantis formalios organizacijos ir neformalių santykių priešstata. Empiriniai pavyzdžiai parodo, kad apstus neformalumas dažnai visiškai nesiekè suardyti formalių organizacijų veiklos centralizuoto sovietinio režimo sąlygomis. Iš tiesų priklausymas formalioms organizacijoms buvo itin svarbus resursas veikèjams, mezgusiems veiksmų tinklus, kurie driekèsi toli už jų formalių organizacijų. Šios oficialiai neleistinos, bet neformaliai sankcionuotos veiklos materialūs rezultatai pastatai ir eksponuojami daiktai - turètų būti traktuojami kaip ribiniai objektai, kurie tuo pačiu metu priklausè skirtingiems reikšmių pasauliams. Tad Jūrų muziejus priklausė daugeliui reikšmių pasaulių, pavyzdžiui, Lietuvos ir Rusijos sovietinès nomenklatūros ir vietinès savivaldybės, muziejaus mokslininkų ir jūreivių, gamtos ir architektūros pasauliams. Todẻl būtų netikslinga tiek muziejų, tiek jị kūrusius veiksmus ir veikejjus redukuoti tik į vieną prasminę kategoriją. 